\title{
INFLUÊNCIA DE ESTRUTURAS GEOLÓGICAS BIDIMENSIONAIS NO CAMPO GEOELETROMAGNÉTICO NA PRESENÇA DO ELETROJATO EQUATORIAL
}

\author{
Marcos Welby Correa Silva \\ Orientador: Dr. Luiz Rijo (UFPA) \\ 112 p. - Tese (Doutorado) - Defesa 28.02.2005
}

RESUMO. A Terra atua como um grande magneto esférico, cujo campo assemelha-se àquele gerado por um dipolo magnético. Este campo apresenta mudanças de intensidade que variam com a localização e a hora local. A parte principal do campo geomagnético se origina no interior da Terra através de processos eletromagnéticos. Extensivos estudos mostraram ainda que existem contribuições de origem externa ao planeta, principalmente de origem solar. Dentre estas fontes há anomalias do campo magnético que surgem a partir de um aumento diurno da corrente elétrica em uma estreita faixa da ionosfera, de direção leste-oeste, centrada no equador magnético e denominada Eletrojato Equatorial (EEJ). Ocasionalmente estas correntes podem apresentar reversões de fluxo, sendo denominadas Contra-Eletrojato (CEJ). Vários autores têm estudado os efeitos do EEJ e CEJ sobre as observações geoeletromagnéticas. Eles estão interessados no efeito combinado do EEJ e estruturas geológicas condutivas 1-D e 2-D. Nestes trabaIhos a estrutura 2-D sempre se apresentava paralela ao eletrojato, 0 que é uma hipótese bastante restritiva ao se modelar ambientes geológicos mais realistas, em que corpos bidimensionais podem ter qualquer strike em relação ao EEJ. Neste trabalho apresentamos a solução deste problema sem esta restrição. Assim, mostramos os campos geoeletromagnéticos devidos a estruturas bidimensionais que possuam strike oblíquo em relação ao EEJ, através de perfis dos campos elétrico e magnéticos calculados na superfície e formando direção arbitrária à heterogeneidade condutiva 2-D. Com esta resposta avaliamos ainda qual a influência que estruturas bidimensionais exercem sobre a resposta magnetotelúrica, sob influência do Eletrojato Equatorial. Durante o desenvolvimento deste trabalho, utilizamos 0 método de elementos finitos, tendo por fonte eletromagnética 0 EEJ e 0 CEJ, que por sua vez foram representados por uma combinação de distribuições gaussianas de densidade de corrente. Estas fontes foram decompostas nas direções paralela e perpendicular à estrutura 2-D, resultando nos modos de propagação $\mathrm{TE}_{1}$ e $\mathrm{TE}_{2}$ e TM acoplados, respectivamente. Resolvemos o modo acoplado aplicando uma Transformada de Fourier nas equaç̃oes de Maxwell e uma Transformada Inversa de Fourier na solução encontrada. De acordo com os experimentos numéricos realizados em um modelo interpretativo da Anomalia Condutiva da Bacia do Parnaíba, formado por uma enorme estrutura de $3000 \mathrm{ohm}-\mathrm{m}$ dentro de um corpo externo condutivo (1 ohm-m), concluímos que a presença do CEJ causa uma inversão na anomalia, se compararmos com o resultado do EEJ. Concluímos também que para as frequêencias mais altas as componentes do campo elétrico apresentam menor influência da parte interna do corpo 2-D do que da parte externa. Já para frequêencias mais baixas este comportamento se observa com as componentes do campo magnético. Com relação à freqüência, vimos os efeitos do "skin-depth", principalmente nas respostas magnéticas. Além disso, quando a estrutura 2-D está paralela ao eletrojato, o campo elétrico é insensivel à estrutura interna do modelo para todos os valores de frequêencia utilizados. Com respeito ao ângulo $\theta_{h}$ entre a heterogeneidade e a fonte, vimos que o modo TM se manifesta naturalmente quando $\theta_{h}$ é diferente de $0^{\circ}$. Neste caso, o modo TE é composto por uma parte devido à componente da fonte paralela à heterogeneidade e a outra devido à componente da fonte perpendicular, que é acoplada ao modo TM. Assim, os campos calculados têm relação direta com o valor de $\theta_{h}$. Analisando a influência do ângulo entre a direção do perfil dos campos e 0 strike da heterogeneidade verificamos que, à medida que $\theta_{h}$ se aproxima de $90^{\circ}$, os campos primários tornam-se variáveis para valores de $\theta_{p}$ diferentes de $90^{\circ}$. Estas variações causam uma assimetria na anomalia e dão uma idéia da inclinação da direção do perfil em relação aos corpos. Finalmente, concluímos que uma das influências que a distância entre o centro do EEJ e 0 centro da estrutura 2-D, causa sobre as componentes dos campos está relacionado às correntes reversas do EEJ e CEJ, pois a $500 \mathrm{~km}$ do centro da fonte estas correntes têm máxima intensidade. No entanto, com o aumento da distância, as anomalias diminuem de intensidade. Nas sondagens MT, nós também usamos 0 EEJ e 0 CEJ como fonte primária e comparamos nossos resultados com a resposta da onda plana. Deste modo observamos que as componentes do campo geoeletromagnético, usadas para calcular a impedância, têm influência do fator de acoplamento entre os modos $\mathrm{TE}_{2}$ e TM. Além disso, esta influência se torna maior em meios resistivos e nas frequêências mais baixas. No entanto, o fator de acoplamento não afeta os dados magnetotelúricos em frequiências maiores de $10^{-2} \mathrm{~Hz}$. Para frequêencias da ordem de $10^{-4} \mathrm{~Hz}$ os dados MT apresentam duas fontes de perturbação: a primeira e mais evidente é devido à presença fonte 2-D (EEJ e CEJ), que viola a hipótese da onda plana no método MT; e a segunda é causada pelo acoplamento entre os modos $\mathrm{TE}_{2}$ e TM, pois quando a estrutura bidimensional está obliqua à fonte 2-D temos correntes elétricas adicionais ao longo da heterogeneidade. Concluímos assim, que 0 strike de uma grande estrutura condutiva bidimensional relativamente à direção 
do EEJ ou CEJ tem de fato influência sobre o campo geomagnético. Por outro lado, para estudos magnetotelúricos rasos (freqüências maiores de $10^{-3} \mathrm{~Hz}$ ) 0 efeito do ângulo entre a estrutura geológica 2-D e a direção do EEJ não é tão importante. Contudo, em estudos de litosfera (freqüências menores de $10^{-3} \mathrm{~Hz}$ ) 0 acoplamento entre os modos $\mathrm{TE}_{2}$ e TM não pode ser ignorado.

ABSTRACT. The Earth acts as a large magnet, whose field resembles one that is generated by a magnetic dipole. This field presents intensity changes that vary with observation location and the local time. The main part of the geomagnetic field is created within the Earth by electromagnetic processes. Extensive studies showed that there are also contributions from outside the Earth, mainly from solar origin. Among these outside sources there are anomalies of the magnetic field that arise from an diurnal increase of the electric current in a narrow strip located in the ionosphere, with east-west direction, centered above the magnetic equator and denominated Equatorial Electrojet (EEJ). Occasionally these currents present flow reversions, therefore denominated Counter-Electrojet (CEJ). Several authors have been studying the effects of the EEJ on the geomagnetic observations. They are interested in the combined effect of the equatorial electrojet and the 1-D e 2-D conductive geological structure underneath. In these works the 2-D structure is always considered parallel to the electrojet, which is a quite restrictive hypotheses in view to realistic geological situation, in that twodimensional structures can have any direction in relation to the electrojet. We present in this work the solution of this problem without this restriction. Thus, here we present the geomagnetic fields due to a two-dimensional structure that possess oblique strike in relation to Equatorial Electrojet, through profiles of the electric and magnetic fields, calculated on the surface and forming arbitrary direction to the 2-D conductive heterogeneity. Further, we also evaluate the influence of an arbitrarily oriented two-dimensional structure would cause on the Magnetotelluric data, under the Equatorial Electrojet. In the development of this work, we applied the method of finite elements with the EEJ and CEJ as electromagnetic source, that was represented by a sum of gaussians distributions of current density. This source was decomposed in the parallel and the perpendicular directions to the 2-D structure, resulting in the mode $\mathrm{TE}_{1}$ and the coupled mode $\mathrm{TE}_{2}$ and $\mathrm{TM}$, respectively. We solved the coupled mode applying a Fourier Transform in the Maxwell equations and one Inverse Fourier Transform in the transformed-domain solution. According to the numerical experiments on a interpretative model of Parnaíba Basin Conductivity Anomaly, formed by a large 3000 ohm-m body inside a very conductive (1 ohm-m) external structure, we conclude that the presence of the CEJ causes an inversion in the anomaly. We also conclude that at high frequencies the components of the electric field present smaller influence of the internal part of the 2-D body than the external part. Otherwise, we observed this behavior in the magnetic field at low frequencies. Varying the frequencies, we saw the effects of the "skin-depth" mainly in the magnetic field. Besides, there are situations where electric field is insensitive to the internal structure of the model for all values of the frequency used. With regard to the angle $\theta_{h}$ between the strike of the conductive heterogeneity and the EEJ direction, we observe the TM mode naturally when $\theta_{h}$ is different from $0^{\circ}$. In this case, the TE mode is composed of two components, one decomposition of the EEJ parallel to the heterogeneity and the other perpendicular to it. As consequence, the $\mathbf{E}$ and B fields have all their three components. When we analyzed the influence of the angle between the direction of the profile of fields and the strike of the 2-D heterogeneity, we conclude that its variation causes an asymmetry on the anomalies, which give an idea about the profile's direction. Finally, we conclude that one of the influences that the distance between the center of the electrojet and center of the 2-D structure causes on the fields is related to the reverse currents, because at $500 \mathrm{~km}$ from the EEJ's center, these currents have their maximum intensity. In the MT soundings, we also used the EEJ and CEJ as primary source and we compared our results with the plane wave response. We noted that the components of the geomagnetic field, used to evaluate the impedance, have an influence from the coupling factor between the $\mathrm{TE}_{2}$ and $\mathrm{TM}$ modes. Moreover, this influence becomes greater with decreasing of the frequency and for resistive host. However, the coupling factor do not affects the MT response at frequencies higher than $10^{-2} \mathrm{~Hz}$. For lower frequencies, about $10^{-4} \mathrm{~Hz}$, we detect two kinds of perturbations on the MT data with respect to the plane-wave one: the first is due the presence of the 2-D electromagnetic source (EEJ and CEJ) as primary field, which violates the plane wave hypothesis; and the second is caused by the coupled TE and TM modes because additional electric currents arise in the heterogeneity's direction when it is oblique to EEJ. These effects increase with the resistivity of the environment. In conclusion, the strike of a large conductive 2-D structure relative to the direction of the EEJ or CEJ do have influence on the geomagnetic field. On the other hand, for shallow magnetotelluric studies (frequencies higher than $10^{-3} \mathrm{~Hz}$ ) the effect of angle between the strike of the 2-D geological structure and the direction of the EEJ is not so important. However, for lithospheric studies (frequencies lower than $10^{-3} \mathrm{~Hz}$ ) the coupling between the two modes can not be ignored. 